Gesnerus 63 (2006) 90-102

\title{
Death in Life and Life in Death: Melancholy and the Enlightenment
}

Allan Ingram

\section{Summary}

This article, which deals with the 17th and 18th centuries, is concerned with the presence of death in the melancholiac's life as revealed in both the accounts written by sufferers themselves and medical works. It shows the exceptional place which melancholiacs consider themselves to occupy, compared to the rest of the living, as they inhabit the no-man's-land between life and death. The privileged status echoes the classical theme of the melancholic genius (Problem $X X X)$. Although some, like George Cheyne or Samuel Johnson, denied the link, this cliché is nevertheless very present in the self-description of the melancholy. Suffering, which is always physical, is a sign of moral superiority.

Keywords: melancholy; George Cheyne (1671?-1743); English malady; depression; suicide; Thomas Gray (1716-1771); accounts of melancholy

'It is November when the English begin to hang themselves' was a commonly held belief among continentals during the eighteenth century, and one given credence by several English writers, including the physician George Cheyne, who, in his famous work The English Malady, published in 1733, blamed the miserable English climate and the effects of the English love of luxury for the national prevalence of melancholia and suicide. There is, in fact, little evidence to suggest that depressed English men and women killed themselves any more frequently than the melancholy mad of other nationalities. Such figures as exist are also complicated by the increasing tendency of

Prof. Allan Ingram, English Division, School of Arts and Humanities, University of Northumbria, Lipman Building, Newcastle upon Tyne NE1 8ST, UK (allan.ingram@northumbria.ac.uk). 
English juries during the period to bring in insanity verdicts on suicide cases. Nevertheless, there was certainly a powerful link within the depressive temperament between personal identity and death that could take a variety of forms, some of them suicidal and some, as I shall be arguing, resistant to suicide.

The melancholike man properly so called ... is ordinarilie out of heart, alwaies fearfull and trembling, in such sort as that he is afraid of every thing, yea and maketh himself a terrour unto himself, as the beast which looketh himself in a glasse; he would runne away and cannot goe, he goeth oftentimes sighing ... with an unseparable sadness, which oftentimes turneth into dispayre; he is alwaies disquieted both in bodie and spirit, he is subject to watchfulness, which doth consume him on the one side: for if he think to make truce with his passions by taking some rest, behold so soone as hee would shut his eyelids, hee is assayled with a thousand vaine visions, and hideous buggards, with fantasticall inventions, and dreadful dreames ... he cannot live with companie. To conclude, hee is become a savadge creature haunting the shadowed places, suspicious, solitarie, enemie to the Sunne, and one whom nothing can please, but onely discontent, which forgeth unto itselfe a thousand false and vaine imaginations ... ${ }^{1}$

These are the characteristics of the melancholy man as described in 1599 by M. Andreas Laurentius, a passage, as Bridget Gellert Lyons points out, that is 'typical' of the literary 'character' - that is, it sets a formulaic 'he' against 'syntactic variation and novelty', allowing thereby the exercise of authorial invention within the presentation of a 'constant type'. The images, the allusions, the patterns of habitual mental and physical eccentricity have a rich potential for literary exploitation, especially satiric and dramatic - Jonson, Donne, Marston, and eventually Milton, spring to mind-, yet the work quoted is in fact a medical one: A Discourse of the Preservation of Sight. If this is indicative of a close proximity between modes of medical writing and more literary forms during the Renaissance, it is also, more relevantly, a sign of the ground already occupied by the melancholiac: he is both a medical phenomenon and a cultural force, a set of recognisable symptoms attributable to a known cause and with predictable consequences, and at the same time the focus for ideas about personality, nature, seeing, belief and indeed the very nature of society itself. The 'glasse' that the melancholy man makes of himself, no less than the articulacy with which, like Hamlet, he expresses his terror, watchfulness and dreams, is a cultural as much as a psychological reflector, and one of particular interest when the society that is looking has reason to think of itself as 'enlightened'.

By the time of the Enlightenment, understanding of the underlying causes of melancholy had gradually shifted, with humoural imbalance being replaced by nervous fragility, depletion or thickening in the blood or weakness in the vital fibres, even though all explanations seemed to result in the same

1 Cited in Lyons 1971, 13. 
basic treatment: bleeding and purging, frequently attended with the various pet therapies put forward by idiosyncratic individual physicians. Culturally, however, the impact of the melancholiac remained a force capable of expression in very similar terms to those of 1599: fearfulness and trembling, for example, for the late seventeenth-century Nonconformist divines Richard Baxter and Timothy Rogers; the comparison of the self with the beast, for George Trosse and for Hannah Allen, also at the end of the seventeenth century; suspicion and watchfulness for the physician Bernard Mandeville's self-portrayal as patient in the dialogues of A Treatise of Hypochondriack and Hysterick Passions; dreams and visions for William Cowper; despair and flight for James Boswell; and all with the capacity to reflect back to the enlightened society and to the enlightened self versions of its understanding of progress, order and civilisation, and of its notions of health, diagnosis and cure.

It is this capacity of the melancholy vision to write in the opposite, or 'other', of all that society, belief and reason hold dear that is picked up in a letter by the poet Thomas Gray, written in 1742 to his close friend Richard West. 'Mine, you are to know,' writes Gray,

is a white Melancholy, or rather Leucocholy ... which though it seldom laughs or dances, nor ever amounts to what one calls Joy or Pleasure, yet is a good easy sort of a state ... But there is another sort, black indeed, which I have now and then felt, that has something in it like Tertullian's rule of faith, Credo quia impossible est; for it believes, nay, is sure of everything that is unlikely, so it be but frightful; and on the other hand excludes and shuts its eyes to the most possible hopes, and everything that is pleasurable; from this the Lord deliver us! ${ }^{2}$

The delicate articulacy of tone possible in a letter between two cultivated individuals should not blind us to Gray's serious analysis of the melancholic vision: it constitutes a denial of everything that makes for social and civilised pleasure, that which is normally immediately apparent to open eyes, and intrudes, instead, an alternative certainty based upon the most primitive, irrational and 'savadge' of instincts, forging 'unto itselfe a thousand false and vaine imaginations'. Denying that life or human intercourse had any possibility of value, it leaves a stark choice, unless 'the Lord deliver us', of evils: death in life, or death itself, the final confirmation of the reality of the 'terrour' that a melancholy man can pose 'unto himselfe'.

The physician Nicholas Robinson, who was known for his severe stance on mental illness, also describes the state of mind of the melancholy madman in A New System of the Spleen, Vapours, and Hypochondriack Melancholy, published in 1729 . Such people 'are subject to very impertinent and groundless fears, that render Life not only uneasy to themselves, but greatly per-

2 Gray 1900-1912, I, 181. 
plexing to all their Friends about them. Sometimes they fancy they are just going to die, and call for their Relations and Neighbours, as if they were immediately about to expire.' Moreover, 'they are continually complaining of their unhappy State of Life, oppressed and overborn with Calamities and Afflictions; no Bodies Pains are equal to their Pains; none knows what they feel and suffer'. While they are capable of being 'cheerful, gay, and agreeably diverting', the 'sullen Fit' will return and 'they are depress'd to the last Degree of Despair'. 'Thus,' concludes Robinson, 'in this disconsolate State, they are a Plague to themselves, their Friends, and all that have any Concern with them.' ${ }^{3}$

It was during 'the last Degree of Despair', or what the late seventeenthcentury Nonconformist divine Timothy Rogers refers to in his Discourse Concerning Trouble of Mind as believing oneself 'to be for a long season even as in Hell it self' ${ }^{4}$, that many melancholy, or hypochondriac, or splenetic individuals felt the temptation towards suicide. The physician John Woodward, in the posthumous work, Select Cases, and Consultations, in Physick, published in 1757 but relating to the early years of the century, describes the case of a gentleman of sixty-five who had at the age of twenty-four been 'invaded with an hypochondriac Affection, and a very deep Melancholy; which he never recovered from to this Day'. This patient 'was wholly subject to his Passions', which were generally 'Anxiety and Grief', 'Fear, Dread, and Horror', and 'Rage and Anger'. 'He seemed,' says Woodward, 'ever to himself as in an Hell upon Earth ... Even his most lucid and comfortable Moments were so dismal and miserable, that he thought Death more desireable.' He was so terrified of becoming completely insane that 'partly to avoid that, and partly to ease himself of that insupportable Burthen of Melancholy, he continually resolved to lay violent Hands upon himself; and several Times attempted it' ${ }^{5}$.

John Woodward's patient survived to be cured by the physician (Woodward gave him 'Purges with Clysters'). Other would-be suicides were more thorough. John Haslam, the apothecary to Bethlem Hospital for a long period at the end of the eighteenth century and the beginning of the nineteenth, records in his Observations on Insanity, published in 1798, the case of a man of fifty whose mind had been disordered 'by too great attention to business, and the want of sufficient rest'. Having been given a month's leave of absence from the hospital, he gradually became 'gloomy and suspicious' until his wife found him one morning 'with his throat cut'. He died some days later, peni-

3 Robinson 1729, 209f.

4 Rogers 1691,3.

5 Woodward $1757,239,242 \mathrm{f}$. 
tent and dispirited, saying that 'it was committed in a moment of rashness and despair'6. Even more dramatic was the death in 1766 of the writer and clergyman John Brown, who was sufficiently well known to have been invited to St Petersburg by Catherine the Great to advise on the reorganisation of Russian education, though the journey never took place. Brown was a lifelong depressive, suffering acutely from what his physician Sir John Pringle referred to as 'an intolerable oppression of Spirits and horror of Mind'. Brown's servant, James Green, according to evidence given before the coroner, was called to his bedchamber on the morning of 23rd September. Green 'went there, and took a Book, \& sat down a Minute or two' before hearing 'a Noise in the Bed like the rattling of a Person's Throat, upon which he went to the Bedside (the Curtains being drawn round the Bed) and saw the Decd. lying on his rightside on the Bed bleeding very much from a Wound on the rightside of his Neck, and that there was a great Deal of Blood on the Bed Cloaths and on the floor'. The coroner's verdict was that 'John Brown Clerk being a Lunatick did give unto himself one mortal wound on the right side of his Neck with a Razor of which he died'7.

Self-destruction, moreover, was rooted in the delusions of the melancholy mad, even if many sufferers proved unable to kill themselves. Hannah Allen described her period of depressive insanity in a pamphlet, $A$ Narrative of God's Gracious Dealings With that Choice Christian Mrs. Hannah Allen, published in 1683. Having fallen into a severe melancholy after the loss at sea of her husband, she was first of all convinced that she would immediately die, 'every morning saying, I should dye before night, and every night, before morning'. She next feared 'that God would not suffer me to dye a natural death; but that I should commit some fearful abomination, and so be put to some horrible death', in consequence of which she determined upon suicide. So, she says, 'I got Spiders and took one at a time in a Pipe with Tobacco, but never scarce took it out, for my heart would fail me's.

To experience the imagined horrors of death while still living, to believe that one's death is imminent, to anticipate a particularly dreadful death, all these seem to have been features of the delusive state of mind of melancholy mad men and women. This interrelatedness between melancholia and death could assume startling proportions in extreme cases. John Haslam reports a deranged widow in Bethlem who became 'suspicious' and 'apprehensive of evil intentions in the people about her', convinced that there was 'a design ... to put her secretly to death'. More horrifyingly, says Haslam, she

6 Haslam 1798, 79.

7 Brown 1998, 152-155.

8 Allen 1683, 24, 31-33. 
fancied that a young man, for whom she had formerly entertained a partiality, but who had been dead some years, appeared frequently at her bed-side in a state of putrefaction, which left an abominable stench in her room. ${ }^{9}$

This makes a stark emblem of the melancholiac's awareness of the irresistible presence of death in life, here fortified by the power of a real personal emotional engagement rendered self-destructive by madness.

The exaggerated conviction of death in life is one insight into the 'horror of Mind', 'the last Degree of Despair', that sufferers from melancholy found so distressing that, as in Brown's case, death itself could be more inviting. But such awareness by no means always took the form of visitations from the dead. James Boswell wrote extensively about his experience of melancholy, both in his journal, which he kept for most of his life, and in a series of anonymous essays published monthly between 1777 and 1783 as The Hypochondriack. In his essay of December 1780 (a month into the season when the English are hanging themselves), on the subject of hypochondria itself, he describes the 'perturbation of spirits' of the hypochondriac, the sufferer from chronic melancholia. This 'perturbation' is characterised by a 'low and desponding' opinion of himself, by everything appearing 'quite indifferent', by his beginning to believe 'that nothing exists without the mind' and that 'The world is one undistinguished wild'. Moreover, he sees nothing 'great or good or agreeable in the situation of others', because 'his corrosive imagination destroys to his own view all that he contemplates', so much so that:

All that is illustrious in publick life, all that is amiable and endearing in society, all that is elegant in science and in arts, affect him just with the same indifference, and even contempt, as the pursuits of children affect rational men.

And he misquotes from Hamlet (a key figure, of course, for the melancholy man, and for the awareness of death in life) the lines 'How weary, stale, flat and unprofitable, To me seen all the uses of this world ${ }^{10}$. Boswell also had, from time to time, thoughts of suicide, but what emerges most pervasively from his remarks is an abiding sense of the vanity of all things human. To the depressive temperament, the inertness of death almost seems preferable to a meaningless existence, for being alive is itself virtually to be in a state of death. So, a patient of the physician Peter Shaw, suffering from 'the lowest degree of melancholy', could reveal that he sometimes 'fancied himself among the damn'd'11.

The melancholy imagination was a medium that cast over all of life the tones of death, so that the state of being of the melancholiac, his very iden-

9 Haslam 1798, 75.

10 Boswell 1951, 208f.

11 Shaw $1724,45$. 
tity itself, seemed a pattern of death in life, just as much as the rotting ghost in the cell at Bethlem. The impression of putrefaction of the dead lover, in the deranged perception of the mad widow, becomes internalised for the melancholiac so that it is his very self, his understanding, his beliefs, his whole personality that are dead from within. The melancholy man believes himself condemned to a life that has no meaning, to inhabit a world that he perceives as a living death.

Moreover, sane observers, too, tended to regard the insane as if they were dead, or at least as if departed from the realm of the living. The poet, Edward Young, for example, wrote in October 1746 to several friends of his concern for an acquaintance, Grace Cole, deranged by grief for the deaths of her parents. To Margaret, Duchess of Portland, Young says that 'We know no more of her, than of ye state of the Dead. She is actually dead to our Manner of Life'. In fact, in that Miss Cole's father, who really was dead, is remembered as 'Captain John Cole', with all the force, rank and personality he had when alive, his deranged daughter is if anything rendered more distant from humanity by being seen as dead while living. As Young continues, 'Let us look on her, as a Living monument of ye realy Deceased ${ }^{12}$.

The insane mind, then, and particularly the melancholy mad mind, as perceived both by sufferers and by the wider sane, is located in a kind of no-man's-land between the living and the dead, neither wholly one nor the other, less alive than the living but, curiously, also less alive than the dead. But it is this sense of being 'in between' that was itself crucial to the sensibilities of eighteenth-century melancholiacs. They were not properly alive, while nevertheless continuing to exist in a world that clearly thought of itself as living. They felt the attractions of oblivion, an escape into suicide, but could still, like Hamlet, fear death and the unknown.

This peculiar 'in-between' balance in the state of mind of the melancholy mad identity is reflected in the expression of melancholia, and especially in the images that the depressive temperament generates - images, often, of transience, or of departure, or of barriers, or of extreme fragility. These images recur both in 'sane' melancholy writing and in expressions from patient histories. The hypochondriac, says Boswell:

cannot fix his attention upon any one thing, but has transient ideas of a thousand things; as one sees objects in the short intervals when the wind blows aside flame and smoke. ${ }^{13}$

William Cowper, the poet and hymn writer, and one of the most depressive Englishmen ever to survive to a natural death, made several attempts at

12 Young 1971, 242f.

13 Boswell 1951, 209. 
suicide in 1763, following which he was taken to Dr Cotton's madhouse in St Albans, where he stayed for eighteen months. During the period of his break-down he had a series of dreams and visions that have several of these 'in-between' features. He dreamt of barriers: he seemed 'to be walking in Westminster Abbey' when he 'heard the minister's voice and hastened towards the Choir; just as I was upon the point of entering, the iron gate under the organ was flung in my face with a Jar that made the Abbey ring'. Another night he awoke believing himself at the moment of death, a 'numbness' seizing upon his extremities, a 'cold sweat ... upon my forehead' while 'my heart seemed at every pulse to beat its last and my soul to cling to my lips as if upon the very point of departure'14.

Such images are apparent, too, in the beliefs of confined patients, for example those recorded by the Leicester physician and madhouse owner, Thomas Arnold. In his classic work, Observations on the Nature, Kinds, Causes, and Prevention of Insanity, published between 1782 and 1786, Arnold reports some of the delusions of which his and other authorities' patients were convinced, delusions that reside in the fear of fragility of the transience of bodily form. There is the man who 'sees flasks of oil, which he does not see' and 'who was in perpetual fear lest they should fall, and be broken'. There are patients who 'have imagined themselves to be made wholly, or in part', of breakable or easily destroyed substances, such as 'wax, butter, glass, leather, or straw'. In particular, Arnold relates, from contemporary English and European authorities, the case of the 'eminent painter who confined himself for a whole winter in bed, imagining all his bones to be as soft and flexible as wax, and not daring to rise, lest, being unable to support his weight, they should give way under their load, and his whole body should sink down into a misshapen globular mass'; and of the man who 'believed his body to be made of butter, and anxiously avoided going near a fire, lest he should melt away'; and of another who 'fancied that his legs were nothing but glass, and for that reason dared on no account venture to stand upon them'. These people quite literally believed themselves to be 'in between' life and death in their very shape and substance. The most chilling delusion, however, and the most precariously fragile image is held by the man who

imagined the whole surface of the earth to be formed of very thin glass, under which he could plainly perceive serpents without number, and would, by no means, be persuaded to get out of his bed; which he conceived to be an island, situated in the midst of this immense glassy expansion; and which, therefore, he dared not to quit, lest, if he should tread on this thin brittle surface, it should break, and suffering him to fall through, he should be devoured, or stung to death, by the serpents underneath. ${ }^{15}$

14 Cowper 1979, 29, 31.

15 Arnold 1806, I, 11f., 123, 126f., 115. 
These, too, are 'horrors of Mind' just as much as seeing death in all of life, or of believing oneself to be among the damned.

If such beliefs, or visions, or images, various and outrageous as they are, leave the melancholy mad individual in a precariously exposed position between life and death, they can also give him or her, in his own mind, a very special significance. He, after all, is the only person to be privileged with so profound an insight into the truth of things. He sees what no one else sees, and if this means that he is inclined to look with frustration at the rest of humankind, as they live their lives in ignorance of the truth, unaware that they too are sharing a world of death, or even that they constitute the body of the damned, there is nevertheless also a sense of pity for their unseeing innocence. As Boswell puts it in a letter from Holland at a time when he was suffering from unremitting depression, 'I saw all things as so precarious and vain that I had no relish of them, no views to fill my mind, no motives to incite me to action. I groaned under those dismal truths which nothing but a lucky oblivion prevents from weighing down the most vivacious souls. ${ }^{16}$

The belief that the melancholiac was possessed of a particular genius, or an especially acute sensitivity, derived from Aristotle, and its currency was good in the eighteenth century despite robust denunciations from, among others, George Cheyne and Samuel Johnson. The heroic tone that melancholy could cast over one's identity is found in Boswell, who continues his letter from Holland by observing that ' $I$ lived in this persuasion for four months ... But I considered myself as a soldier. I endured such hardships; but I kept my post.' The ability to survive mental and emotional pain might not bestow genius, but it at least gives a kind of dignity to the experience and a nobility to the identity of the miserable individual. Notions of duty, dependability, resolution, and even of self-sacrifice begin to make themselves felt under the surface of the suffering, and the idea that somehow the melancholiac is not only 'in between' life and death but, as such, is also, and much more importantly, standing between humanity and some form of impending disaster.

Nicholas Robinson writes with a high degree of resentment against madmen with a mission, the religious enthusiasts who claim 'the highest Degree of Familiarity with their Maker' and see themselves as 'his Viceroys, chosen Saints and Servants, sent on especial Errands, to reclaim the unbelieving World ${ }^{17}$. However, these are not the melancholy mad, even though melancholiacs, too, can be understood in a distinctly religious light, as Timothy Rogers does. For Rogers, those afflicted with 'Trouble of Mind' are suffered by 'the Wise God' to 'feel the bitterness of Sin and the terrors of his amazing-

16 Boswell 1952, 206.

17 Robinson 1729, 246. 
wrath' so that 'when they are delivered, they may warn those that are at ease, that they beware of Sin, lest it bring them also into a state so dreadful and so terrible" ${ }^{18}$.

Rogers clearly defines the scope and significance of the melancholiac's suffering. He or she is not instructed by God to perform, like Christ himself, a divinely ordained mission that is crucial to His plans for mankind. Rather, the melancholy mad man or woman is closer to the scapegoat, the sacrifice, suffering on behalf of their innocent, ignorant fellows, holding back through their sole effort a catastrophic global fate. In fictional terms, this is the figure of Johnson's astronomer in Rasselas, convinced that he has acquired the ability to control the weather, which he has done for many years to the benefit of mankind, and now is distraught that his eventual death will leave the world to the unrelenting mercy of the elements. But in patient histories, as Thomas Arnold reports, there are similar cases of real obsessives, individuals labouring to stave off universal disaster through their own suffering. One woman 'continually held up her middle finger, on which she imagined she was supporting the whole earth, and was in perpetual anxiety lest she should suffer her finger to give way, and destroy the world, with its inhabitants'. Again, a man

believed himself to be ATLAS, carrying the world on his back; and was in much anxiety lest it should fall, and not only crush himself, but all mankind, to atoms.

Or, in a particularly painful case, a man

imagined that he had so vast a quantity of urine within him, that he was afraid of making water, lest his friends and neighbours should be drowned in the deluge it might produce. ${ }^{19}$

The best-documented case, however, as well as one of the most extraordinary of obsessions, is that of James Tilly Matthews, as recorded in John Haslam's book, Illustrations of Madness, which was published in 1810. A long-term inmate of Bethlem, Matthews believed that he was the victim of a gang of 'event-working' villains who inhabited 'some apartment near London Wall' and who assailed him day and night by means of a machine called an 'Air Loom'. The rays of this machine produced a variety of devastating physical effects on Matthews, for example 'Sudden death-squeezing; by them termed Lobster-cracking', which was 'an external pressure of the magnetic atmosphere surrounding the person assailed, so as to stagnate his circulation, impede his vital motions, and produce instant death'. In Matthews' words, the experience is like being 'in a sufficiently large pair of nut-crackers, or lobstercrackers, with teeth, which should pierce as well as press him through every

18 Rogers $1691,3$.

19 Arnold 1806, I, 116, $133 f$. 
particle within and without ${ }^{20}$. In this sense alone, Matthews is firmly located 'in between' life and death, between the efforts of the gang and his own resilience and hold on identity. However, as well as his physical suffering, Matthews also felt himself to be a scapegoat, or stand-in, or even potentially a saviour of his kind, in that the gang was, he believed, a force from revolutionary France, sent to subdue him as the only person in the country who knew of their existence and activities. All of the senior figures in the government and armed forces were, unawares, under the control of these and similar forces: Matthews alone stood between freedom and submission to France. His resistance was therefore crucial, against death at their hands, and against the tyranny and terror they represented. Indeed, Matthews' obsessions also took on not merely national but cosmic significance, as the gang agreed in referring to him as 'the talisman', as if he was himself the charm or protection against some universal curse. Moreover, Matthews felt that he was a key, or channel, for revealing the fate of mankind: that 'there was the figure of a man on the top of Bloomsbury Church who had got a Book under his Arm. That it was the Doomsday book, and that no one could open that book but himself. ${ }^{21}$

Thomas Gray, less spectacularly than Matthews, but more accessibly, projects himself, most notably in the Elegy Written in a Country Churchyard, as an in-between figure, and one that actualises its presence through traditional images of melancholy perception: 'solitarie', 'haunting the shadowed places', 'enemie to the Sunne', and having himself described, after his own imagined death within the poem as formerly 'smiling as in scorn', as 'Muttering his wayward fancies', and 'drooping, woeful wan, like one forlorn, / Or crazed with care, or crossed in hopeless love' (11. 105-108) ${ }^{22}$. For Gray, once tolled into 'darkness', has, like the patients described by Arnold and Haslam, a responsibility in which he stands as a crucial intermediary, in his case between the dead and the living, an interpreter of the silences of past lives for those living who, afflicted with the common frailties of the living - 'Ambition', 'Grandeur', pride (11. 29, 31, 37) -, have need of 'the voice of nature' (1.92) as mediated through the melancholy sensibility of the poet to restore an awareness of their seamless common humanity. This takes the form, in part, of a conventional momento mori:

The boast of heraldry, the pomp of power,

And all that beauty, all that wealth e'er gave,

Awaits alike the inevitable hour.

The paths of glory lead but to the grave. (11.33-36)

20 Haslam 1988, 32.

21 Haslam 1988, 24, lii.

22 Gray 1969, 103-141. Line numbers are given in the text. 
As the poem proceeds, however, it is clear that Gray is looking to engage a more imaginative identification both with the dead and with the process of dying - and it is one that preempts his own eventual departure from the poem in fictitious death:

For who to dumb Forgetfulness a prey,

This pleasing anxious being e'er resigned,

Left the warm precincts of the cheerful day,

Nor cast one longing, lingering look behind? (11. 85-88)

So, when the poet, concluding the Elegy with his own epitaph, records, silent now because himself among the not quite 'unhonoured dead' (1.93), not only that 'Large was his bounty and his soul sincere' (1.121) but that 'Melancholy marked him for her own' (1.120), it is a significant recognition of a force within the melancholy temperament. The cycle of self-absorption, solitariness, and fearfulness has also come to include a generosity of outlook that genuinely seeks to embrace erring humankind, to act as its eyes, its conscience, its suffering better self, its capacity for illumination. The melancholy poet waits for darkness and the things of night, representing thereby the death-centred other of the enlightened society, but he also brushes 'with hasty steps the dews away / To meet the sun upon the upland lawn' (11. 99-100). He is, after his absorption into darkness, the man who welcomes the light, who would reconnect his kind with generosity, bountifulness and sincerity.

'About suffering they were never wrong, The Old Masters' (ll. 1-2), wrote W. H. Auden in our own time ${ }^{23}$. If being 'never wrong' involves claiming the entitlement to dignify one's suffering while acquiescing in enduring it, we may readily go along with Auden's lines, for who can have the right to pass judgment on another's suffering, however outlandish the means whereby it is survived. James Tilly Matthews' case is no doubt the most extreme to have come down to us, and his attempt at dignifying is one of the most lavish and unlikely, but the pattern is representative. Everything in the melancholy mad individual's existence is liable to act as a pull towards death, and it is a pull that some depressives, like the unfortunate John Brown, found irresistible. But for many melancholiacs, the delusions that drew them towards death also saved them from it. As 'in-betweeners', as protectors of their fellows, it became the duty of the sufferers to resist the temptations of self-destruction and to carry on living for the benefit of normal, if slightly inferior, members of humankind. 


\section{Bibliography}

Allen, Hannah, A Narrative of God's Gracious Dealings With that Choice Christian Mrs. Hannah Allen (London 1683)

Arnold, Thomas, Observations on the Nature, Kinds, Causes, and Prevention of Insanity, 2 vols (London 1806)

Auden, W. H., "Musée des Beaux Arts”, in: Collected Shorter Poems (London 1966)

Boswell, James, Boswell's Column (The Hypochondriack, 1777-1783), ed. by Margery Bailey (London 1951)

- Boswell in Holland, 1763-1764, ed. by F. A. Pottle (London 1952)

Brown, John, "Report of the Coroner's Inquest into the Death of John Brown, 1766", in: Ingram, Allan (ed.), Patterns of Madness in the Eighteenth Century: A Reader (Liverpool 1998)

Cowper, William, "Memoir of the Early Life of William Cowper, Esq. (Adelphi)", in: King, James/Charles Ryskamp (eds), The Letters and Prose Writings of William Cowper, I, 1750-1781 (Oxford 1979)

Gray, Thomas, The Letters of Thomas Gray, ed. by D. C. Tovey, 3 vols (London 1900-1912)

- The Poems of Gray, Collins and Goldsmith, ed. by Roger Lonsdale (London 1969)

Haslam, John, Observations on Insanity (London 1798)

- Illustrations of Madness, ed. by Roy Porter (London 1988)

Lyons, Bridget Gellert, Voices of Melancholy (London 1971)

Robinson, Nicholas, A New System of the Spleen, Vapours, and Hypochondriack Melancholy (London 1729)

Rogers, Timothy, A Discourse Concerning Trouble of Mind and the Disease of Melancholy (London 1691)

Shaw, Peter, The Juice of the Grape; or, Wine Preferable to Water (London 1724)

Woodward, John, Select Cases, and Consultations, In Physick (London 1757)

Young, Edward, The Correspondence of Edward Young, 1683-1765, ed. by Henry Pettit (Oxford 1971) 